ISSN 0206-5657. Вісник Львівського університету. Серія біологічна. 2018 Випуск 78. С. 6-7 Visnyk of the Lviv University. Series Biology. 2018. Issue 78. P. 6-7

\title{
JUST HERBARIZE IT!? UP-TO-DATE COLLECTING, PRESERVING AND DOCUMENTING OF PLANT MATERIAL FOR SCIENTIFIC PURPOSES
}

\author{
C. Pachschwoell
}

\author{
University of Vienna \\ 14, Rennweg St., Vienna 1030, Austria \\ e-mail: clemens.pachschwoell@univie.ac.at
}

\begin{abstract}
This talk is dealing with up-to-date techniques of collecting, preserving and documenting of plant material from the temperate flora of Central and Eastern Europe following recommendations in literature as well as own experiences. On the one hand, the collection of plant material has become more bureaucratic with the Nagoya protocol, but on the other hand it is now much easier due to technical advances. Apart from collecting standard herbarium specimens, special cases like water plants, parasites (e.g. Orobanchaceae) and bulbiferous plants (e.g. Amaryllidaceae, Asparagaceae, Liliaceae) will be addressed. Another topic will be the different techniques of drying plants material for herbarium specimens as well as in silica gel for future molecular studies. With the rise of NGS techniques like Illumina sequencing, even well preserved historical plant material from herbaria can be used. Sequencing of the whole plastid and ribosomal DNA ("genome skimming") from herbarium specimens is now a hot topic in herbarium genomics. The second part of the talk will deal with the documentation of localities with the help of GPS devices, Online Maps (historical and recent maps), (Online) Encyclopedias, Online Databases and Smartphone Apps. Noteworthy freely available apps are OSMAnd, LocusMap and Oruxmaps which can be used totally offline, whereas Google Maps only can be used temporarily offline with prior download of a defined region. For floristic mapping, the app Geopaparazzi is recommended, for converting of GPS files several online tools as well as the desktop program GPSBabel are useful. Especially for beginners or scientists with limited budget, the freeware QGIS is recommended, as maps for figures in publications can be produced there in a more straightforward way than in the propriety software ArcGIS.
\end{abstract}

\section{ЛИШЕ ГЕРБАРИЗУВАТИ!? ЗБІР, ЗБЕРЕЖЕННЯ ТА ДОКУМЕНТУВАННЯ ЗІБРАНИХ МАТЕРІАЛІВ ДЛЯ НАУКОВИХ ЦІЛЕЙ}

\section{Pachschwoell}

\author{
Віденський університет \\ вул. Реннвет 14, Відень 1030, Австрія \\ e-mail: clemens.pachschwoell@univie.ac.at
}

\begin{abstract}
Ця доповідь стосується сучасних методів збору, збереження і документування рослинного матеріалу з помірної флори Центральної та Східної Європи за рекомендаціями в літературі, а також із власного досвіду. 3 одного боку, збір рослинного матеріалу став більш бюрократизованим за протоколом Нагоя, але, з іншого боку, тепер це набагато простіше завдяки технічним досягненням. Окрім збору стандартних зразків гербарію, будуть розглянуті особливі випадки, такі як гербаризація водяних рослин, паразитів (наприклад, Orobanchaceae), цибулинних рослин (наприклад, Amaryllidaceae, Asparagaceae, Liliaceae). Іншою темою будуть різні методи сушіння рослинного матеріалу для гербарію і в силікагелі для майбутніх молекулярних досліджень. 3 появою методів NGS, таких як Illumina, можна використовувати навіть добре збережений історичний рослинний матеріал із гербарію. Секвенування всієї
\end{abstract}

C) Pachschwoell C., 2018 
пластидної та рибосомної ДНК («genome skimming») зразків гербарію є тепер гарячою темою гербарної геноміки.

Друга частина доповіді стосується документування місцевостей за допомогою GPS-пристроїв, онлайнових карт (історичних і нещодавніх карт), інтернет-енциклопедій, онлайн-баз даних та програм для смартфонів. Примітними вільно доступними додатками $є$ OSMAnd, LocusMap та Oruxmaps, які можуть бути використані цілком автономно, тоді як карти Google можуть бути тимчасово використані в автономному режимі 3 попереднім завантаженням карти певного регіону. Для флористичного картування рекомендується додаток Geopaparazzi, для перетворення GPS-файлів корисними $є$ кілька онлайнових інструментів, а також настільна програма GPSBabel. Спеціально для початківців або вчених з обмеженим бюджетом рекомендовано безкоштовну QGIS, оскільки цифрові карти для публікацій можуть бути виготовлені простішим способом, ніж у програмному забезпеченні ArcGIS. 